\section{Behavior of Listeria innocua during the manufacturing and pit-ripening of Formaggio di Fossa di Sogliano PDO cheese}

Federica Giacometti, ${ }^{1}$ Paolo Daminelli,

Laura Fiorentini, ${ }^{2}$ Elena Cosciani-

Cunico, ${ }^{2}$ Paola Monastero, ${ }^{2}$

Elena Dalzini, ${ }^{3}$ Marina-Nadia Losio, ${ }^{2}$

Giovanni Dell'Orfano, ${ }^{4}$

Rachele Rossini, ${ }^{5}$ Silvia Piva, ${ }^{1}$

Andrea Serraino ${ }^{1}$

${ }^{1}$ Department of Veterinary Medical

Sciences, University of Bologna, Ozzano dell'Emilia; ${ }^{2}$ Experimental

Zooprophylactic Institute in Lombardy

and Emilia Romagna, Brescia; ${ }^{3}$ National

Reference Centre for Emerging Risks in

Food Safety, Experimental

Zooprophylactic Institute in Lombardy and Emilia-Romagna, Milan; ${ }^{4}$ Public Health Unit of Cesena, U.O.D. Igiene degli alimenti di Origine Animale, ForlìCesena; ${ }^{5}$ Antiche Fosse s.a.s, Sogliano al Rubicone, Forlì-Cesena, Italy

\section{Abstract}

Formaggio di Fossa di Sogliano is a traditional Italian Protected Designation of Origin (PDO) cheese ripened for a minimum of 5 months, with the feature of a ripening of at least 80 to at most 100 days in pits, digged into tuffaceous rocks according to medieval tradition of Italy. In this study, a challenge test using Listeria innocua as a surrogate of Listeria monocytogenes was performed, with the aim of increasing knowledge concerning the impact of the Fossa cheese process, and especially of the traditional ripening process of this PDO, on the behaviour of $L$. monocytogenes. Pasteurized milk was experimentally inoculated with $4.5 \mathrm{log}$ CFU/mL cocktail by three $L$. innocua strains, and L. innocua and Mesophilic Lactic Acid Bacteria (LAB) counts as well as the evolution of temperatures, $\mathrm{pH}$ and $\mathrm{a}_{\mathrm{w}}$ values were monitored throughout the manufacturing and ripening processes. Throughout the ripening in maturation room a constant temperature of $8^{\circ} \mathrm{C}$ was observed reaching a temperature between 10 and $15.5^{\circ} \mathrm{C}$ during ripening into pit. In the final products data for LAB concentration, $\mathrm{pH}$ and $\mathrm{a}_{\mathrm{w}}$ values were roughly in accordance with literature, even if some differences were, probably due to variability of artisanal cheese productions. The numbers of $L$. innocua showed a slight decrease but remained stable until the end of ripening in maturation room, whereas a significant reduction of the microorganism was observed in the final product, at the end of the ripening into the pit. The findings give scientific evidence that the process of this PDO prevented the L. innocua growth, allowing us to speculate a similar behaviour of L. monocytogenes. Based on this study, the recommendation to extend as much as possible the ripening into pit (from 80 to 100 days) was provided to food business operators as a risk mitigation strategy to be implemented.

\section{Introduction}

Italy has a prominent position in the European dairy industry being the largest producer country of Protected Designation of Origin (PDO) cheeses. The main use for cow milk in Italy is for cheese making: milk destination is productions of PDO cheeses (44\%), followed by other destinations $(39 \%)$, fresh milk (9\%) and UHT milk (9\%) (CLAL, 2019). A total of 527,105 tonnes of PDO cheeses were produced in 2016 in Italy (CLAL, 2019). Formaggio di Fossa di Sogliano, henceforth Fossa cheese, is registered as PDO by the European Community (EC) regulations (EC, 2009). Fossa cheese is a semi-hard cheese, produced using whole pasteurized milk, either from cow or sheep or a mixture of both, with the peculiarity of cheese ripening for a minimum of 5 months, of which the first 60 days take place in a maturation room, following by a variable period from at least 80 to at most 100 days in ripening pits, digged into tuffaceous rocks, that are prepared and sealed according to tradition originated in the Middle Ages (Avellini et al., 1999; De Santi et al., 2010; Gobbetti et al., 1999). This peculiar ripening has important effects for hardness, moisture, flavour and for the development of some organoleptical properties that characterize this traditional cheese (Barbieri et al., 2011; De Santi et al., 2010; Fontana et al., 2010; Pirisi et al., 2011).

Dairy production follows several stages, from raw milk production at the farm and further processing either at a dairy company or at the farm itself, and food safety hazards may enter at various stages along this dairy supply chain (van Asselt et al., 2017). Based on the Rapid Alert System for Food and Feed (RASFF) database on food safety hazards in dairy products for 2009 to 2014 , a total of 243 notifications were retrieved, of which 203 were microbiological contaminations, and most of these involved cheese products. Listeria monocytogenes is involved in 52\% of these notifications for microbiological
Correspondence: Federica Giacometti, Dipartimento di Scienze Mediche Veterinarie, Università di Bologna, Via Tolara di Sopra, 50, 40064 (BO), Italy

Tel.: +39.051 2097320 - Fax: +39.051.2097346. E-mail: federica.giacometti3@unibo.it.

Key words: Challenge test; Listeria monocytogenes behavior; ready to eat food; risk mitigation.

Contributions: the authors contributed equally.

Conflict of interests: the authors declare no potential conflict of interests.

Acknowledgements: The authors wish to thank Conti Marinella and Raduano Luciano, owner's of the dairy plant Caseificio Pascoli, for the Fossa cheese manufacturing, and Rossini Gianfranco, owner of the pit Antiche Fosse s.a.s, for the pit ripening.

Funding: None.

Received for publication: 10 September 2019. Revision received: 9 February 2020.

Accepted for publication: 10 February 2020

This work is licensed under a Creative Commons Attribution-NonCommercial 4.0 International License (CC BY-NC 4.0).

(C) Copyright: the Author(s), 2020

Licensee PAGEPress, Italy

Italian Journal of Food Safety 2020; 9:8552

doi:10.4081/ijfs.2020.8552

contamination (van Asselt et al., 2017), and from 2015 to hitherto, other one hundred alerts for L. monocytogenes, categorized as serious risk, were notified by EU Countries in the product category milk and milk products. In the context of food safety, food business operators (FBO) are responsible for ensuring that the requirements of food law are met within the food business under their control (Regulation EC No 178/2002), and Regulation EC 2073/2005 sets out microbiological criteria for foodstuffs, including food safety criteria for Listeria monocytogenes in Ready-To-Eat (RTE) foods at specific time points along the food chain and as a function of the type of food. In fact, RTE foods are a broad and diverse food category, some of which support the growth of $L$. monocytogenes and others that do not or even result in microbial inactivation in specific storage and shelf life conditions (EFSA, 2018); the critical limit for this food safety criteria that must be satisfied depends on the evidence that the considered RTE food is able or not to support L. monocytogenes growth: products with $\mathrm{pH} \leq 4,4$ or $\mathrm{a}_{\mathrm{w}} \leq 0,92$, or products with 
$\mathrm{pH} \leq 5,0$ and $\mathrm{a}_{\mathrm{w}} \leq 0,94$, or products with $\mathrm{a}$ shelf-life of less than five days shall be automatically considered to belong to this category, but, other categories of products can also belong to this category, subject to scientific justification (Regulation EC No 2073/2005).

When pasteurized milk is used for cheese making, the contamination by $L$. monocytogenes can be due to unsatisfactory pasteurization or contamination after heat treatment (Lomonaco et al., 2009) and in the specific case of soft-ripened cheese made of pasteurized milk, the factors influencing the risk of illness by L. monocytogenes are cross-contamination or re-contamination during manufacturing (linked to the hygiene of the processing environment) and the evolution of L. monocytogenes population during the ripening.

Few studies were performed on Fossa cheese, and they were mostly focused on characterization of the cheese composition and of the bacterial or fungal microflora in the cheese and in its ripening environment.

This study is the first challenge test performed on Fossa cheese, where a postpasteurisation contamination of milk by Listeria innocua was simulated, and followed the traditional manufacturing and ripening of this Italian PDO cheese in real tuffaceous pit, filled up and opened only after the pit ripening as the PDO specification. In this scenario, L. innocua was choosen as surrogate of $L$. monocytogenes given the use of $L$. monocytogenes as inoculum was avoided for the consequent risk of cheese environment contamination.

\section{Materials and Methods}

\section{Milk collection and preparation of milk inoculum}

A total of 150 L of cow's milk, provided by the Didactic Dairy Farm and pasteurized $\left(63^{\circ} \mathrm{C}\right.$ for $30 \mathrm{~min}$ ) by Didactic Dairy Plant of the Department of Veterinary Medical Sciences, University of Bologna, Italy, were used. The milk was then transported, in refrigerated conditions, to the pilot plant of the Istituto Zooprofilattico Sperimentale della Lombardia e dell'Emilia Romagna (IZSLER) within 24 hours after pasteurization.

Three L. innocua strains (one type strain: ATCC $^{\circledR} \quad 3390^{\mathrm{TM}}$ and two wild strains belonging to IZSLER's collection: Li 48775 isolated from milk and Li 39673/2 isolated from butter) were used to contaminate the pasteurized milk. The bacterial cultures were prepared following the protocol described by Dalzini et al. Briefly, each strain, kept frozen $\left(-80^{\circ} \mathrm{C}\right)$ in Brain Heart Infusion (BHI) (Oxoid Italia, Milan, Italy) supplemented with $20 \%$ glycerol, was transferred $(2 \%$ inoculum) into $\mathrm{BHI}$, incubated at $37^{\circ} \mathrm{C}$ for $24 \mathrm{~h}$ in aerobic conditions and grown for two successive cultures. The cultures were centrifuged at $4^{\circ} \mathrm{C}$ at $4000 \mathrm{~g}$ (Jouan centrifuge CR422, Winchester, VA, USA) and the supernatant fluids were immediately drawn off and discarded. The pellet was washed with sterile physiological solution $\left(\mathrm{H}_{2} \mathrm{O}\right.$ with $\left.0.9 \% \mathrm{NaCl}\right)$, centrifuged and resuspended in sterile physiological solution. Before use, the individual strains were combined in equal volumes in order to obtain a multistrain cocktail. Once warmed to $38^{\circ} \mathrm{C}, 150 \mathrm{~L}$ of milk were inoculated with $1 \% v: v$ of multi-strain cocktail of $L$. innocua to reach approximately $4.5 \log \mathrm{CFU} / \mathrm{mL}$ in milk. The number of viable cells of the suspension was verified in milk before cheesemaking by 10 -fold dilution and direct plating on Listeria selective agar (Oxford Formulation) (Oxoid Italia, Milan, Italy) plates incubated at $37^{\circ} \mathrm{C}$ for $48 \mathrm{~h}$.

\section{Formaggio di Fossa di Sogliano}

PDO process

Fossa cheese was manufactured

\begin{tabular}{|c|c|}
\hline $\begin{array}{l}\text { Milk collection and } \\
\text { pasteurization }\end{array}$ & $\begin{array}{l}-150 \mathrm{~L} \text { of bovine milk were collected } \\
\text {-the milk was pasteurized }\left(60^{\circ} \mathrm{C} \text { for } 30 \text { minutes) }\right. \\
\text {-the milk was transported to the pilot plant }\end{array}$ \\
\hline $\begin{array}{l}\text { Preparation of the inoculum } \\
\text { and milk contamination }\end{array}$ & $\begin{array}{l}\text {-a multi-strain cocktail with three } L \text {. innocua strains was prepared } \\
\text {-the pasteurized milk was inoculated in order to reach } 4.5 \text { log colony forming unit (CFU) } \\
\text { mL. of milk }\end{array}$ \\
\hline $\begin{array}{l}\text { "Formaggio di Fossa di } \\
\text { Sogliano" PDO process in the } \\
\text { pilot plant }\end{array}$ & $\begin{array}{l}\text {-cheeses were manufactured according to traditional production specifications (milk once } \\
\text { cooled to } 38^{\circ} \mathrm{C} \text { was inoculated with starter cultures and cheese rennet, the coagulum is } \\
\text { cut and then crumbled into small cubes that are transferred to moulds) } \\
\text {-a total of } 18 \text { cheeses were manufactured } \\
\text {-introduction of data loggers in three inoculated cheeses }\end{array}$ \\
\hline $\begin{array}{l}\text { Fossa cheese ripening in } \\
\text { maturation room }\end{array}$ & $\begin{array}{l}\text {-the cheeses were transported to a ripening plant at Sogliano di Rubicone } \\
\text {-the cheeses were dry-salted by spreading the salt over the cheesewith Salt of Cervia, } \\
\text { washed and turned for the whey removal } \\
\text {-the cheeses were ripened } 60 \text { days in maturation room }\end{array}$ \\
\hline $\begin{array}{c}\text { Fossa cheese ripening into } \\
\text { tuffaceous pit }\end{array}$ & $\begin{array}{l}\text {-the cheeses were ripened into a tuffaceous pit at Sogliano di Rubicone } \\
\text {-pit was prepared according the tradition, with a floor of wooden boards and walls lined } \\
\text { with layers of straw; the pit was filled up with the cheeses wrapped in natural cotton } \\
\text { bags and recognized with laces } \\
\text {-the pit was hermetically sealed from the end of January to the end of April allowing } 93 \\
\text { days of cheeses ripening into the pit }\end{array}$ \\
\hline
\end{tabular}

Figure 1. Flowchart reporting the main steps of the experimental study's design and of the analyses performed. 
according to production specification (MIPAAF, 2009). For the cheese making, milk was inoculated with starter culture (STMM, B.M.B. s.r.l. Manufacturing \& Trade, Bologna, Italy), which contain Streptococcus thermophilus, Lactococcus lactis subsp. cremoris, Lactococcus lactis subs. lactis, Lactococcus lactis subs. lactis biovar. diacetylactis, Leuconostoc mesenteroides, and cheese rennet for the milk coagulation (Micromilk 20g/50 L of milk). The coagulum was cut for two successive times in order to crumble it into small cubes of about $0.5-1 \mathrm{~cm}$, transferred into round moulds $(20 \mathrm{~cm}$ diameter and 10 height) and the lets stand at room temperatures for 2 hours, turning the moulds upside down for a total of 3 times.

A total of 18 cheeses of about $800 \mathrm{~g}$ each, were manufactured in this study. All the cheeses were transported to a dairy plant at Sogliano di Rubicone, Emilia-Romagna Region, Italy. Cheeses were stored at room temperature $\left(22 \pm 2^{\circ} \mathrm{C}\right)$ for $18 \mathrm{~h}$, and then, dry-salted by spreading the salt over the cheese, and again put into the moulds for 8 9 hours. After washing, cheeses were put again into the moulds for $48 \mathrm{~h}$ at room temperature $\left(22 \pm 2^{\circ} \mathrm{C}\right)$. The cheese wheels were removed from the moulds, moved and placed in appropriate ripening iron steels grills in the ripening room. During these 60 days of ripening, all the cheese wheels were turned every 8 hours in the first week, and then once a day up to 30 days, and once every 3-4 days up to 60 days of ripening.

After the first ripening in room, cheeses were wrapped in natural cotton bags and differentiated with laces for the second and traditional ripening into pit. The pit was prepared with a floor of wooden boards and walls lined with layers of straw, and it was filled up with the cheeses of this study and also with other $40,000 \mathrm{Kg}$ of cheeses. The experimental cheeses were put, within the pit, at three

different points of the pit, respectively at the bottom, in the middle and at the opening of the pit.

Finally, the pit was hermetically sealed from the end of January to the end of April, and after 93 days, it was opened: overall, Fossa cheeses were ripened for a total of 153 days. The 18 experimental Fossa cheeses, items of the challenge test, were transported to the IZSLER laboratory. Figures 1 and 2 show, respectively, the flowchart reporting the main steps of the experimental study's design and some pictures of the cheese ripening.

\section{Sampling, microbiological and physicochemical analyses}

Three replicate samples of $25 \mathrm{~g}$ were collected during cheese making (milk and curd) and during the ripening at 7,30,60 and 153 days (cheese) and prepared according to ISO $6887 \square 1$ (ISO, 1999) and ISO 6887 $\square 5$ (ISO 2010) for the analyses. The microbiological analyses were performed on milk, curd and cheeses: for curd and cheeses, samples were first transferred separately into plastic one-chamber filter stomacher bags (NEOMED, Milan, Italy) and then homogenized for $3 \mathrm{~min}$ in a Stomacher 400 blender (Seward Medical, London, UK) with $225 \mathrm{~mL}$ of $0.1 \% w / v$ of Buffered Peptone Water (BPW) (containing 1\% $v / v$ of Tween
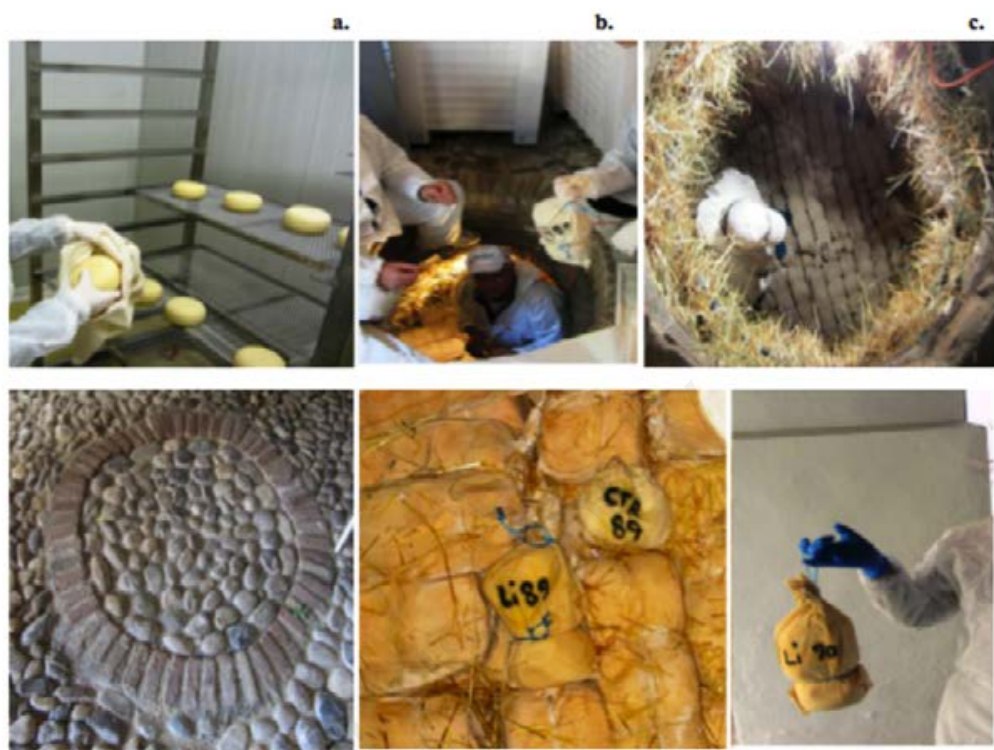

d.

e.

Figure 2. Images showing the cheeses during the ripening in room and into pit performed during the challenge test, according to the specifications of Formaggio di Fossa di Sogliano PDO cheeses. a) after the ripening in room, the cheese wheels were wrapped in natural cotton bags for the ripening into pit; $b$ and $c)$ the pit was filled with the inoculated cheeses; d) the pit was hermetically sealed; e) the pit was opened after 93 ripening days; f) the Formaggio di Fossa di Sogliano PDO cheeses, items of the challenge test, were transported to the laboratory for analyses.

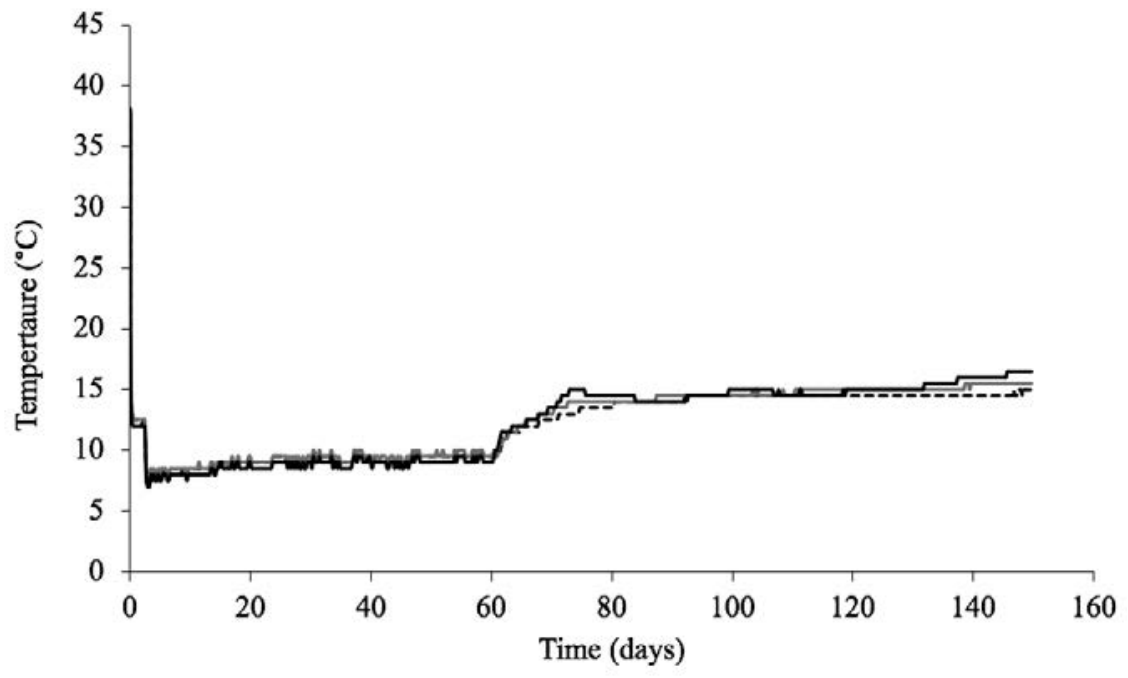

Figure 3. Temperature profiles registered in three experimental cheeses during the cheese making and the ripening (bottom of the pit) (- -$)$ (middle of the pit) (-) (opening of the pit) (-) of Formaggio di Fossa di Sogliano PDO cheeses. 
80 and $0.85 \% w / v$ of $\mathrm{NaCl}, \mathrm{pH} 7.0 \pm 0.2$ ).

To verify the absence of natural contamination, milk was analyzed at time 0 for the presence of $L$. monocytogenes according to ISO 11290-1 (ISO, 2004). The enumeration of $L$. innocua was performed by 10 -fold dilution and plating $(0.1 \mathrm{~mL})$ on Listeria selective agar (Oxford Formulation) (Oxoid Italia, Milan, Italy) plates incubated at $37^{\circ} \mathrm{C}$ for $48 \mathrm{~h}$. Mesophilic Lactic Acid Bacteria (LAB) were enumerated according to ISO 15214 (ISO, 1998). For each culture medium, the quality has been evaluated in accordance with ISO 11133-1 (ISO, 2009) and ISO 11133-2 (ISO, 2011). All the microbiological analysis were performed according to ISO 7218 (ISO, 2007).

For the physiochemical analyses, $\mathrm{pH}$ was measured on $10 \mathrm{~g}$ of samples using an HI 223 Calibration check ${ }^{\mathrm{TM}}$ Microprocessor $\mathrm{pH}$ meter (Hanna Instrument, USA) equipped with a Gel-Glass electrode (Hamilton, Switzerland); water activity $\left(\mathrm{a}_{w}\right)$ was measured at $25^{\circ} \mathrm{C}$ with the $a_{w}$ recorder AquaLab, series 3, Model TE (Decagon Devices, Inc., Pullman, USA) in accordance with ISO/FDIS 21807 (ISO, 2004) and the time/temperature profiles during cheese making and ripening were monitored directly into the milk, curd and cheeses using electronic data loggers (Thermo Button 22T, Astori tecnica s.n.c. Brescia, Italia).

\section{Data analysis}

Bacterial counts were converted to log $\mathrm{CFU} / \mathrm{g}$ or $\mathrm{mL}$. The individual means and standard deviations of microbiological and physicochemical results were determined on the basis of the average of three replicate. The difference of results during the manufacturing process and in relation to the different positions in the pit, were evaluated by variance analysis (ANOVA) by Fisher test. Significance was evaluated when the $p-$ value was lower than $0.05(\mathrm{P}<0.05)$ in this case a Tukey's HSD (Honest Significant
Difference) test was performed to reveal significant changes using R v 3.4.0 software (R Development Core Team, 2008).

\section{Results and Discussion}

During each manufacturing and ripening step for the production of Formaggio di Fossa di Sogliano PDO cheeses, temperature profiles are shown in Figure 3 whereas the evolution of L. innocua and LAB counts as well as $\mathrm{pH}$ and $a_{w}$ values are reported in Table 1. In the first hours of the cheese making, temperature decreased from $38^{\circ} \mathrm{C}$ to $21^{\circ} \mathrm{C}$ until the beginning of the ripening stage and again decreased to $8^{\circ} \mathrm{C}$, remaining constant throughout the ripening in maturation room (Figure 3).

LAB counts increased significantly $(\mathrm{P}<0.05)$ in the first hours reaching $6.93 \pm$ $0.16 \log \mathrm{CFU} / \mathrm{g}$ in the curd (Table 1), and produced a mild gradual but significant decrease in $\mathrm{pH}$ values $(\mathrm{P}<0.05)$ from 6.66 to 5.00 at day 60 due to the production of organic acids. Once into the pit, the observed temperatures increased from 10 to $15^{\circ} \mathrm{C}$ with changes accordingly to the position of the cheeses into the pit (Figure 3) and in case of cheeses placed in the opening of the pit, the observed temperatures, moving up and down until the end of pit ripening, were probably due to the greater effect of the external environment and climate. With respect to the published data, Authors reported temperatures throughout the ripening time ranging from 25 to $16^{\circ} \mathrm{C}$ depending on the moment of the ripening (usually temperatures were higher in the beginning of the ripening and began to drop slowly almost at the end of the ageing into the pit) and with variations depending on the season of the ripening. Our findings were lower to studies of Avellini et al., 204; De Santi et al., 2010; Mascaro et al., 2010 but in line with Toppino et al., 1992. The final products, cheeses placed in the bottom of the pit and ripened for 93 days in pit, were characterized by a LAB concentration of $6.86 \pm 0.39 \mathrm{log}$ $\mathrm{CFU} / \mathrm{g}$, a $\mathrm{pH}$ value of $5.06 \pm 0.06$ and $\mathrm{a}_{\mathrm{w}}$ of $0.916 \pm 0.002$ showing no differences in relation to the position of the cheeses into the pit (Table 1). Data we observed for LAB concentration in the final products were in accordance with those reported in literature studies: Barbieri et al. (2011) showed a LAB concentration of about $6 \log$ counts in 150 day-old cheese ripened 90 days in a pit, Fontana et al. (2010) reported a level of $6.92 \pm 0.76 \log \mathrm{CFU} / \mathrm{g}$ on Fossa cheese surface, as well as a wide variability from 5.8 to $7.8 \log$ count was observed by Gobetti et al. (1999) in Fossa cheese at the end of the ripening in pit.

Our results were in agreement with literature also for the $\mathrm{pH}$ values, varying between 5.00 and 5.75 (Toppino et al., 1992; Gobbetti et al., 1999; Mascaro et al., 2010), while the final $a_{w}$ values were slightly higher than those observed by Gobetti et al. (1999) but similar to Mascaro et al. (2010). This variability could be due to the fact that artisanal production of cheese is not completely standardized, and therefore, it creates variability in intrinsic product characteristic, mainly in case of semi hard cheese that are fermented products with a variable and dynamic microbial community that is still biological active during further storage (Lahou et al., 2017).

The success of this challenge test is related to the fact that $L$. innocua behaviour should be evaluated during the whole 5 months of manufacturing process: given this behaviour is unknown both during the cheese manufacturing and the long ripening time into pit, a high concentration of the inoculum was chosen, in agreement NACMCF (2010), to prevent undetectable or not significant findings. In addition, the absence of L. monocytogenes in milk used

Table 1. Evolution of L. innocua and Mesophilic Lactic Acid Bacteria (LAB) counts (Log CFU/g), and of pH and $a_{w}$ values during cheese making and ripening of Formaggio di Fossa di Sogliano PDO cheeses experimentally contaminated. Values are mean of the three replicates samples \pm standard deviation.

\begin{tabular}{|c|c|c|c|c|c|c|c|}
\hline \multirow{2}{*}{ Parametersa } & \multicolumn{2}{|c|}{ Cheese making } & \multicolumn{3}{|c|}{ Ripening in room for 60 days } & \multicolumn{2}{|c|}{ Ripening into pit for 93 days } \\
\hline & Milk & Curd & $\begin{array}{l}\text { Cheese } \\
\text { at } 7 \text { days }\end{array}$ & $\begin{array}{l}\text { Cheese } \\
\text { at } 32 \text { days }\end{array}$ & $\begin{array}{l}\text { Cheese } \\
\text { at } 60 \text { days }\end{array}$ & $\begin{array}{l}\text { Cheese } \\
\text { at } 153 \text { days }\end{array}$ & \\
\hline L. innocu ${ }^{\mathrm{a}}$ & $4.51 \pm 0.02^{\mathrm{A}}$ & $4.35 \pm 0.04^{\mathrm{A}}$ & $4.22 \pm 0.09^{\AA}$ & $4.36 \pm 0.20^{A}$ & $3.89 \pm 0.26^{\mathrm{B}}$ & $\begin{array}{l}\text { Middle } \\
\text { Opening }\end{array}$ & $\begin{array}{l}2.49 \pm 0.83^{c} \\
2.32 \pm 0.73^{c}\end{array}$ \\
\hline $\mathrm{LAB}$ & $4.97 \pm 0.66^{\mathrm{AA}}$ & $6.93 \pm 0.16^{\mathrm{B}}$ & $7.32 \pm 0.17^{\mathrm{B}}$ & $7.4 \pm 0.22^{\mathrm{B}}$ & $6.86 \pm 0.39^{\mathrm{B}}$ & $\begin{array}{l}\text { Middle } \\
\text { Opening }\end{array}$ & $\begin{array}{l}6.47 \pm 0.86^{\mathrm{B}} \\
6.40 \pm 0.29^{\mathrm{B}}\end{array}$ \\
\hline $\mathrm{pH}$ & $6.66 \pm 0.02^{\mathrm{A}}$ & $5.79 \pm 0.03^{\mathrm{B}}$ & $5.48 \pm 0.06^{\mathrm{C}}$ & $5.13 \pm 0.16^{\mathrm{D}}$ & $5.00 \pm 0.03^{\mathrm{D}}$ & $\begin{array}{l}\text { Middle } \\
\text { Opening }\end{array}$ & $\begin{array}{l}5.15 \pm 0.09^{\mathrm{D}} \\
5.11 \pm 0.06^{\mathrm{D}}\end{array}$ \\
\hline$a_{w}$ & n.p. & $0.997 \pm 0.002^{\mathrm{A}}$ & $0.960 \pm 0.009^{B}$ & $0.940 \pm 0.014^{\mathrm{B}}$ & $0.914 \pm 0.016^{\mathrm{C}}$ & $\begin{array}{l}\text { Middle } \\
\text { Opening }\end{array}$ & $\begin{array}{l}0.916 \pm 0.005^{c} \\
0.918 \pm 0.004^{c}\end{array}$ \\
\hline
\end{tabular}

n.p.: not performed. 
for the experiment was verified. The $L$. innocua concentration remained essentially unchanged from day 0 to day 32 of the ripening in maturation room (from $4.51 \pm 0.02$ to $4.36 \pm 0.20 \log \mathrm{CFU} / \mathrm{g}$ ) and only at the end of the ripening at 60 days showed a significant decrease $(\mathrm{P}<0.05)$ to $3.89 \pm 0.26 \log \mathrm{CFU} / \mathrm{g}$ (Table 1); the final concentration of $L$. innocua was $2.92 \pm 0.20$ $\log \mathrm{CFU} / \mathrm{g}, 2.49 \pm 0.83 \mathrm{log} \mathrm{CFU} / \mathrm{g}$ and 2.32 $\pm 0.73 \log \mathrm{CFU} / \mathrm{g}$ after the ripening respectively in the bottom, middle and in opening of the pit, showing significant reductions $(\mathrm{P}<0.05)$ from a minimum of 1.33 to a maximum of $2.95 \log \mathrm{CFU} / \mathrm{g}$ among the tested replicates.

This study is the first microbiological challenge test performed on Fossa cheese and it gives scientific evidence that the process of this PDO prevented the $L$. innocua growth. Factors affecting $L$. monocytogenes growth, and in general of Listeria spp., mainly include the product characteristics $\left(\mathrm{pH}, \mathrm{a}_{\mathrm{w}}\right.$, concentration of antimicrobials, food preservatives), storage temperature and time. The microstructure of the food matrix can also affect the growth by imposing physical constraints on microorganisms, by limiting the diffusion of essential nutrients and oxygen or preventing the diffusion of metabolic products (Aspridou et al, 2014; EFSA, 2018). Additional factors that can affect $L$. monocytogenes growth is the presence of competitive microflora as well as the socalled Jameson effect, which is expressed as L. monocytogenes growth cessation when lactic acid bacteria reach a critical population density markedly higher than $L$. monocytogenes (Lardeux et al., 2015). During the pit ripening, cheeses maintained intrinsic variables $\left(\mathrm{a}_{\mathrm{w}} \square 0.92\right.$ and $\mathrm{pH}$ around 5.1) values that may be hostile for the bacterial survival as L. innocua. The combination of these hurdles, low $\mathrm{pH}$ and $\mathrm{a}_{\mathrm{w}}$ and high LAB population for long times (over 93 ripening days) probably played a key role in the behaviour of L. innocua. In addition, for the extrinsic variable temperature that could let the bacteria growth, similarly to findings observed by Valero et al. (2014) for a traditional semihard aromatic cheese typically aged for three to six months in which the impact of temperature on L. monocytogenes behavior was investigated during storage at 4,12 and $22^{\circ} \mathrm{C}$, the observed temperatures into pit (increasing from 10 to $15^{\circ} \mathrm{C}$ ) could have produced the significant reduction of $L$. innocua. However, as observed by Lahou and Uyttendaele (2017) from several challenge tests in different dairy products, $L$. monocytogenes growth is significantly higher in pasteurized than raw milk cheeses, given more bacterial competition is expected to be present in raw milk cheeses, which may be an explanation of the lower growth potential of L. monocytogenes in these cheeses (Izquierdo et al., 2009; Mellefont et al., 2008; Schvartzman et al., 2011). In this challenge test, an high amount of L. innocua inoculum in a pasteurized milk with no or very low competitors was performed, and therefore, a non-specific competition for nutrients by the microrganism and the indigenous microflora present in the matrix could be considered, but only the competition with starters cultures. A limitation of our challenge test, in terms of extending our findings to a similar behaviour of L. monocytogenes during the process of this PDO, could be identify in the use of $L$. innocua. L. innocua is described as an attractive surrogate for $L$. monocytogenes due to its close genetic relationship (Glasser et al., 2001) and in literature it has been used in a variety of systems designed to control the growth, eliminate the presence, or reduce the transmission of this foodborne pathogen in foods. However, O'Bryan et al. (2006) observed that $L$. innocua surrogate strains may not accurately reflect the behavior of $L$. monocytogenes in all test conditions/foods, including thermal and other stresses responses. This suggestion should be taken into account considering that the growth of L. monocytogenes is among the most important factors affecting the risk of human listeriosis associated with consumption of RTE foods and that its growth was pointed out to be a function of the type of food and storage conditions (EFSA, 2018). In this context, the pit ripening seems the key point for the control of $L$. innocua and $L$. monocytogenes in this PDO cheese, and the risks to human health could be reduced to an acceptable level by both the containing of the Listeria contamination during cheese making and an appropriate ripening period into the pit. Based on the results of this challenge test, the recommendation to food business operator for risk mitigation to extend as much as possible the ripening into pit according to the Fossa Cheese specification (from 80 to 100 days) was provided, and a further L. innocua decay trend during shelf life at refrigerated temperatures is expected. Obviously, the maintenance of Good Hygiene Practice at primary production and during cheese making is suggested: avoidance of Listeria contamination in milk remains of high priority for the dairy industry.

\section{Conclusions}

The present challenge test is the first to investigate the behavior of L. innocua, as surrogate of L. monocytogenes, in the Formaggio di Fossa di Sogliano cheese process, and mostly in traditional ripening process of this PDO. This study can be considered an useful example of the European food safety approach, with the integration of self-control by food business operator, food companies and the monitoring and auditing by Veterinary Competent Authority. The application of microbial criteria is one of the essential activities to ensure that ready to eat foods presented a low risk to public health, and even in these experimental unrealistic conditions, the numbers of $L$. innocua showed a significant reduction in the final product, at the end of the ripening into the pit. These findings give scientific evidence that the process of this PDO prevented the L. innocua growth, allowing us to speculate a similar behaviour of $L$. monocytogenes. The recommendation of extending the ripening time alignes the need to control of L. monocytogenes in a more proactive way by implementing an effective food safety management system.

\section{References}

Aspridou Z, Moschakis T, Biliaderis CG, Koutsoumanis KP, 2014. Effect of the substrate's microstructure on the growth of Listeria monocytogenes. Food Res Int 64:683-91.

Avellini P, Clementi F, Trabalza Marinucci M, Cenci Goga B, Rea S, Branciari R, Cavallucci C, Reali C, Di Antonio E, 1999. Pit cheese: compositional, microbiological and sensory characteristics. Ital J Food Sci 11:317e333

Barbieri E, Schiavano GF, De Santi M, Vallorani L, Casadei L, Guescini M, Gioacchini AM, Rinaldi L, Stocchi V, Brandi G, 2012. Bacterial diversity of traditional Fossa (pit) cheese and its ripening environment. Int Dairy J 23:627.

CLAL S.r.l. 2019. Available from: https://www.clal.it/en/ Accessed 05 September 2019.

Commission Regulation (EC) No. $1183 / 2009$ of 30 November 2009 entering a name in the register of protected designations of origin and protected geographical indications (Formaggio di Fossa di Sogliano (PDO). OJEU L 317:34-35.

Commission Regulation (EC) No. $2073 / 2005$ on microbiological criteria for foodstuffs. OJ L 338:1-26.

Dalzini E, Cosciani-Cunico E, Bernini V, Bertasi B, Losio MN, Daminelli P, 
Varisco G, 2015. Behaviour of Escherichia coli O157 (VTEC), Salmonella Typhimurium and Listeria monocytogenes during the manufacture, ripening and shelf life of low fat salami. Food Control 47:306-11.

De Santi M, Sisti M, Barbieri E, Piccoli G, Brandi G, Stocchi V, 2010. A combined morphologic and molecular approach for characterizing fungal microflora from a traditional Italian cheese (Fossa cheese). Int Dairy J 20:465-71.

EFSA, 2018. Listeria monocytogenes contamination of ready-to-eat foods and the risk for human health in the EU. EFSA J 16:e5134. European Food Safety Authority.

Fontana C, Cappa F, Rebecchi A, Cocconcelli PS, 2010. Surface microbiota analysis of Taleggio, Gorgonzola, Casera, Scimudin and Formaggio di Fossa Italian cheeses. Int J Food Microbiol 138:205-11.

Glaser P, Frangeul L, Buchrieser C, Rusniok $\mathrm{C}$, Amend A, Baquero F, Berche P, Bloecker H, Brandt P, Chakraborty T, Charbit A, Chetouani F, Couve E, de Daruvar A, Dehoux P, Domann E, Dominguez-Bernal G, Duchaud E, Durant L, Dussurget O, Entian KD, Fsihi H, Garcia-Del Portillo F, Garrido P, Gautier L, Goebel W, Gomez-Lopez N, Hain T, Hauf J, Jackson D, Jones LM, Kaerst U, Kreft J, Kuhn M, Kunst F, Kurapkat G, Madueno E, Maitournam A, Vicente JM, Ng E, Nedjari H, Nordsiek G, Novella S, de Pablos B, Perez-Diaz JC, Purcell R. Remmel B, Rose M, Schlueter T, Simoes N, Tierrez A, Vazquez-Boland JA, Voss H, Wehland J, Cossart P, 2001. Comparative genomics of Listeria species. Science 294:849-52. https://doi.org/

10.1126/science. 1063447.

Gobbetti M, Folkertsma B, Fox PF, Corsetti A, Smacchi E, De Angelis V, Rossi J, Kilcawley J, Cortini M, 1999. Microbiology and biochemistry of Fossa (pit) cheese. Int Dairy J 9:763-73.

ISO, 1998. International Organizational for Standardization. Microbiology of food and animal feeding stuffs - Horizontal method for the enumeration of mesophilic lactic acid bacteria - Colonycount technique at 30 degrees $\mathrm{C}^{\circ}$. ISO 15214:1998.

ISO, 1999. Microbiology of food and animal feeding stuffs - Preparation of test samples, initial suspension and decimal dilutions for microbiological examination - Part 1. General Rules for the Preparation of the Initial Suspension and Decimal Dilutions. ISO 6887$1: 1999$.

ISO, 2004. Microbiology of food and animal feeding stuffs - Horizontal method for the detection and enumeration of Listeria monocytogenes - Part 1: Detection method. ISO 11290-1:1996/Amd 1:2004.

ISO, 2004. Microbiology of food and animal feeding stuffs. Determination of Water Activity. ISO/FDIS 21807:2004.

ISO, 2007. Microbiology of food and animal feeding stuffs - General requirements and guidance for microbiological examinations. ISO 7218:2007.

ISO, 2009. Microbiology of food and animal feeding stuffs - Guidelines on preparation and production of culture media - Part 1: General guidelines on quality assurance for the preparation of culture media in the laboratory. ISO/TS 11133-1:2009.

ISO, 2010. Microbiology of food and animal feeding stuffs - Preparation of test samples, initial suspension and decimal dilutions for microbiological examination - Part 5: Specific rules for the preparation of milk and milk products. ISO 6887-5:2010.

ISO, 2011. Microbiology of food and animal feeding stuffs - Guidelines on preparation and production of culture media - Part 2: Practical guidelines on performance testing of culture media. ISO/TS 11133-2:2011.

Izquierdo E, Marchioni E, Aoude-Werner D, Hasselmann C, Ennahar S, 2009. Smearing of soft cheese with Enterococcus faecium WHE 81, a multibacteriocin producer, against Listeria monocytogenes. Food Microbiol 26:1620.

Lahou E, Uyttendaele M, 2017. Growth potential of Listeria monocytogenes in soft, semi-soft and semi-hard artisanal cheeses after post-processing contamination in deli retail establishments. Food Control 76:13-23.

Lardeux AL, Guillier L, Brasseur E, Doux C, Gautier J, Gnanou-Besse N, 2015. Impact of the contamination level and the background flora on the growth of Listeria monocytogenes in ready-to-eat diced poultry. Lett Appl Microbiol 60:481-90.

Lomonaco S, Decastelli L, Nucera D, Gallina S, Manila Bianchi D, Civera T, 2009. Listeria monocytogenes in Gorgonzola: subtypes, diversity and persistence over time. Int J Food Microbiol 15:516-20.

Mascaro N, Stocchi R, Ricciutelli M,
Cammertoni N, Renzi F, Cecchini S, Loschi AR, Rea S, 2010. Biogenic amine content and chemical and physical features of italian Formaggio di Fossa. Ital J Food Safety, 8:49-52.

Mellefont L, McMeekin T, Ross T, 2008. Effect of relative inoculum concentration on Listeria monocytogenes growth in co-culture. Int J Food Microbiol 121:157-68.

MIPAAF, 2019. Specification of Formaggio di Fossa di Sogliano. Ministero delle Politiche Agricole e forestali. https://www.politicheagricole.it/flex/cm/ pages/ServeBLOB.php/L/IT/IDPagina/3 340 Accessed: September $5^{\text {th }}, 2019$.

NACMCF, 2010. Parameters for determining inoculated pack/challenge study protocols. J Food Protect 73:140202.

O'Bryan CA, Crandall PG, Martin EM, Griffis CL, Johnson MG, 2006. Heat resistance of Salmonella spp., Listeria monocytogenes, Escherichia coli O157:H7, and Listeria innocua M1, a potential surrogate for Listeria monocytogenes, in meat and poultry: A review. J Food Science 71:R23-R30.

Pirisi A, Comuniana R, Urgegheb PP, Scintua MF, 2011. Sheep's and goat's dairy products in Italy: Technological, chemical, microbiological, and sensory aspects. Small Ruminan Res 101:10212.

Schvartzman MS, Maffre A, TenenhausAziza F, Sanaa M, Butler F, Jordan K, 2011. Modelling the fate of Listeria monocytogenes during manufacture and ripening of smeared cheese made with pasteurised or raw milk. Int J Food Microbiol 145:31-8.

Toppino PM, Drava G, Contarini G, Manfredini M, Emandi GC, 1992. Caratteristiche di tipicità del "formaggio di fossa”. Rivista della Società Italiana di Scienza dell'Alimentazione 4:389414.

Valero A, Hernandez M, De Cesare A, Manfreda G, González-García P, Rodríguez-Lázaro D, 2014. Survival kinetics of Listeria monocytogenes on raw sheep milk cured cheese under different storage temperatures. Int J Food Microbiol 184:39-44.

van Asselt ED, van der Fels-Klerx HJ, Marvin HJP, van Bokhorst-van de Veen H, Nierop Groot M, 2017. Overview of food safety hazards in the european dairy supply chain. Compr Rev Food Sci Food Saf 16:59-75. 